family workshop to compete against the large factory. In the Jura department, communal workshops have placed four hundred electric lathes at the disposal of the woodworkers. This utilisation of electric power by cottages has an effect in keeping the country dwellers from drifting to the larger cities, and thus mitigates some of the social problems which many nations are finding so difficult at the present time. In Great Britain, the transmission system- the gridwill soon supply cheap electric power to several country districts. In these districts it will be possible to establish suitable village industries on a commercial basis. In time this should have the effect of easing the economic crisis. Probably training schools for craftsmanship will have to be established. If electric power is sufficiently cheap, small electric motors should enable the weaving industries to flourish in villages.

Studies of Geophysical Methods, 1928 and 1929

The Geological Survey of the Canadian Department of Mines has published, as Memoir 165 (Ottawa, pp. 225 ; 1931, 45 cents), a valuable account, under the above title, of an impartial investigation of various methods of geophysical prospecting. Electrical methods were applied in 1928 to the Abana mines property, Quebec, by generous permission of the owning company, and three electrical prospecting companies accepted an invitation from the Geological Survey to demonstrate their methods on this comparatively suitable deposit; the work was done at their own expense, under the observation of officers, both physical and geological, of the Survey. The geological, electric, and magnetic surveys showed that the physical conditions existing in the Abana mineral deposits are complex, but that, nevertheless, the magnetic and electric methods of prospecting, when used intelligently, are feasible and productive of valuable results. The work in any new area must still be to a large extent an original research, requiring the use of highly trained and skilled men. Further work on the Abana property, and elsewhere, was done in 1929, partly in co-operation with the U.S. Bureau of Mines and (in gravity work) with the Dominion Observatory of Canada. At the Errington Mine, Ontario, an area was met "for the first time" where, in the present state of our knowledge, geophysical methods were of small avail, and where the diamond drill under the direction of geologists and mining engineers was the sole guide to further discovery.

\section{Actinometric Bibliography}

THE Association of Meteorology of the International Union for Geodesy and Geophysics, at its Stockholm meeting in 1930, gave a subvention for the preparation of a bibliography, or rather a series of short abstracts, of papers on actinometry. These are prepared under the supervision of M. Wehrlé, secretary of the Association, at the French National Meteorological Office, by M. Volochine; where possible, the abstract is provided by the author, and English, French, and German versions of the abstracts are available, at the choice of subscribers. Each abstract is on a single leaflet, of convenient size for binding; the leaflets are well reproduced by litho- graphy from typescript. The normal annual number of leaflets will be $300-400$, but the bibliography is to be retrospective, covering the last thirty years; this work, involving about 2000 leaflets, being planned to occupy about two years. The leaflets are to be sent to subscribers in packets of fifty. Subscriptions are invited, though the amount of subscription will not be fixed until the demand for the leaflets is ascertained; it is expected, however, to be about 120 francs per year (for 400 leaflets), and 600 francs for the retrospective bibliography (for 2000 leaflets). Intending subscribers should write to M. Wehrlé, at l'Office Nationale Météorologique, Paris.

\section{Turquoise Mosaic Plaque from Chichen Itza}

A mosaic plaque of turquoise and jade, it is announced by Science Service, of Washington, D.C., has been discovered under the Castillo mound, in the ruined city of Chichen Itza, Yucatan. This announcement recalls the discovery, also at Chichen Itza, of a similar plaque-one of the most remarkable objects of the art of the ancient Mayas ever found-which was made in 1928 by an expedition sent out by the Carnegie Institution of Washington. This plaque was made of turquoise mosaic on a foundation of wood, which had perished. The services of a museum expert. were requisitioned from New York for its removal. The operation of salvage, which necessitated the improvisation of a special technique on the spot, took three months to complete. The plaque was exhibited for the first time at the International Congress of Americanists which met in New York in September 1928. The plaque which has recently been found is described. as a mosaic of turquoise and jade, and, like the preceding find, is on a foundation of wood, now decomposed. It lies in a stone box under a number of fragile articles not yet removed. The tomb under the mound appears to be a secondary burial, and turquoise spearheads may indicate that the occupant was a warrior.

\section{Announcements}

The Alexander Pedler Lecture of the British Science Guild will be given this year, under the joint auspices of the Burton-on-Trent Natural History and Archæological Society and the Guild, at Burton-onTrent on Nov. 4, by Prof. F. T. G. Hobday, principal and dean of the Royal Veterinary College, London. Prof. Hobday's lecture will be entitled "Animals as a National Asset and Responsibility". The Nor. man Lockyer Lecture of the Guild will be delivered on Nov. 22 by Sir Frank E. Smith, secretary of the Department of Scientific and Industrial Research.

Applications are invited for the following appointments, on or before the dates mentioned :-A lecturer in electrical engineering at the Leicester College of Technology-The Registrar (Sept. 12). A lecturer in physiology for education students at the University of Leeds--The Registrar (Sept. 15). A lecturer in physical chemistry at Auckland University College, University of New Zealand-The Secretary of the Universities Bureau of the British Empire, 88A Gower Street, W.C.l (Oct. 10). An assistant bacteriologist at the Royal Institute of Public Health-The Secretary, 23 Queen Square, W.C.1.

No. 3280, VoL. 130] 